\title{
Oryx Tour to Botswana and Zambia
}

\section{David Jenkins}

Thirteen members of the FPS, escorted by Dr David Jenkins, received a very special welcome in Botswana and Zambia last July/August. Not only did they see a wealth of wildlife, they were entertained and helped by conservationists and addressed by the Zambian Minister of State; they were also able to hear from and have discussions with workers in the field which gave them an insight into some conservation problems and made their trip 'very worthwhile'.

The tour lasted nineteen days, most of it in Zambia, but a visit to Chobe National Park in north-east Botswana was extremely fruitful. We arrived unfortunately when the Game Department biologists were away, but Mr Tom Butynski, a Peace Corps biologist from Gaborone, came to talk to the party and Mr Oscar Charlton led our excursions into the bush. Highlights included an afternoon spent with a herd of elephants, some not too friendly, and spectacular glimpses of game along the river against the setting sun.

In Zambia, both the Wildlife Conservation Society and individual members, and the Wildlife Department warmly welcomed and entertained the party, and the Minister of State came to address us at a reception given by the Society. Bob Dowsett spent the best part of two days showing us the wildlife of the Livingstone district, including excellent views of teita falcons in the Zambezi gorges, and Col. and Mrs Critchley entertained us for a day at Blue Lagoon where we saw many water birds, scores of lechwe, wild dogs and much else. Mr John Clarke, Director of the Wildlife Department and eight other wildlife biologists gave their time to speak to or guide us. Mrs Prue Smith and her friends at Livingstone entertained us, Miss Wendy Reece came with us to Blue Lagoon, and Mr Nick Abel spent some days with us in Luangwa. From this it will be clear that the reputation of the FPS stands high in Zambia and members of Oryx Tour No. 14 felt privileged to be delegates of our Society in Central Africa. We are much indebted to our hosts, and Zambia looks to the FPS for continued support on an international scale.

With so much help and interest our tour was bound to be successful. On the Kafue Flats we learned about problems in conserving lechwe-mainly associated with alleviating the effects of crowding animals in confined grazings at times of peak floods-and the threats from new dams. The Luangwa and Kafue National Parks provided a striking contrast in land form and management problems. Wildlife abounds in Luangwa, and is easily seen by the most casual tourist; in Kafue it has to be sought out. The elephant devastation in the Luangwa has to be seen to be fully appreciated. Mature mopane trees are being pushed over at a rate of about four per cent a year, more in some places (according to Dr Caughley), 
and practically all the young mopane trees in the Mfuwe district have been pollarded at about six feet, a height at which they fail to produce seeds. Acacia woodlands have been similarly devastated. But not all the destruction is due to elephants, and the wildlife biologist advising on management has to take into account that much of the mopane is in any case regenerating extremely slowly and that changes in water table can also eliminate forests locally. Predicting the effects of an elephant cull is not straightforward, particularly bearing in mind that the Luangwa elephants (unlike others in similar situations elsewhere) still have a healthy reproductive rate.

Management problems also occur with hippo, which reach densities of 30-100 per river mile. High hippo populations are associated with eroded river banks, sometimes influencing the water table in neighbouring soils, and a reduction in the taller riverside sedges and grasses. This may have secondary effects in encouraging the smaller grazing antelopes. Impala and puku are remarkably abundant in areas of short grass, and the effects of their heavy grazing on vegetation and soils poses more problems for the range ecologist.

Insight into these and other problems made our trip very worthwhile. We also saw lots of wildlife. Few birds escaped hawkeyed Turtle and Corley Smith, and few mammals were missed by lynx-eyed Milner-Bennetts and East, but the mere spectacle was enhanced by our understanding of the management problems underlying the preservation of this wealth for the future. The Conservation Society of Zambia is vigorous and strong; we all joined, and look forward to receiving our copies of their journal Black Lechwe to keep us in touch with our friends in the conservation field in Zambia.

\section{From Stockholm to Nairobi}

At its autumn 1972 meeting the United Nations set up the UN Environment Programme, with a Council on which 58 nations are represented, and a headquarters in Nairobi, Kenya. Maurice Strong, who so ably ran the Stockholm Conference, from which UNEP arises, was elected the first Executive Director. An Environment Fund, financed on a voluntary basis, was established, to provide additional finance for environmental programmes, and June 5 was designated as World Environment Day, when all governments and UN organisations are urged to undertake, every year, world-wide activities re-affirming their concern for the preservation and enhancement of the human environment. It all represents a good beginning, but there is a very long way to go.

\section{Nigeria's Mammals}

In the last issue of Oryx, September 1972, a note on 'Mammals in Nigeria' was unfortunately printed without its last paragraph. This reads:

Predators. The caracal Felis caracal is found throughout Nigeria except in the forest zone. The golden cat $F$. aurata has not been recorded from Nigeria but it occurs in that part of the Cameroon, e.g. near Mamfe, which was formerly part of Nigeria. 


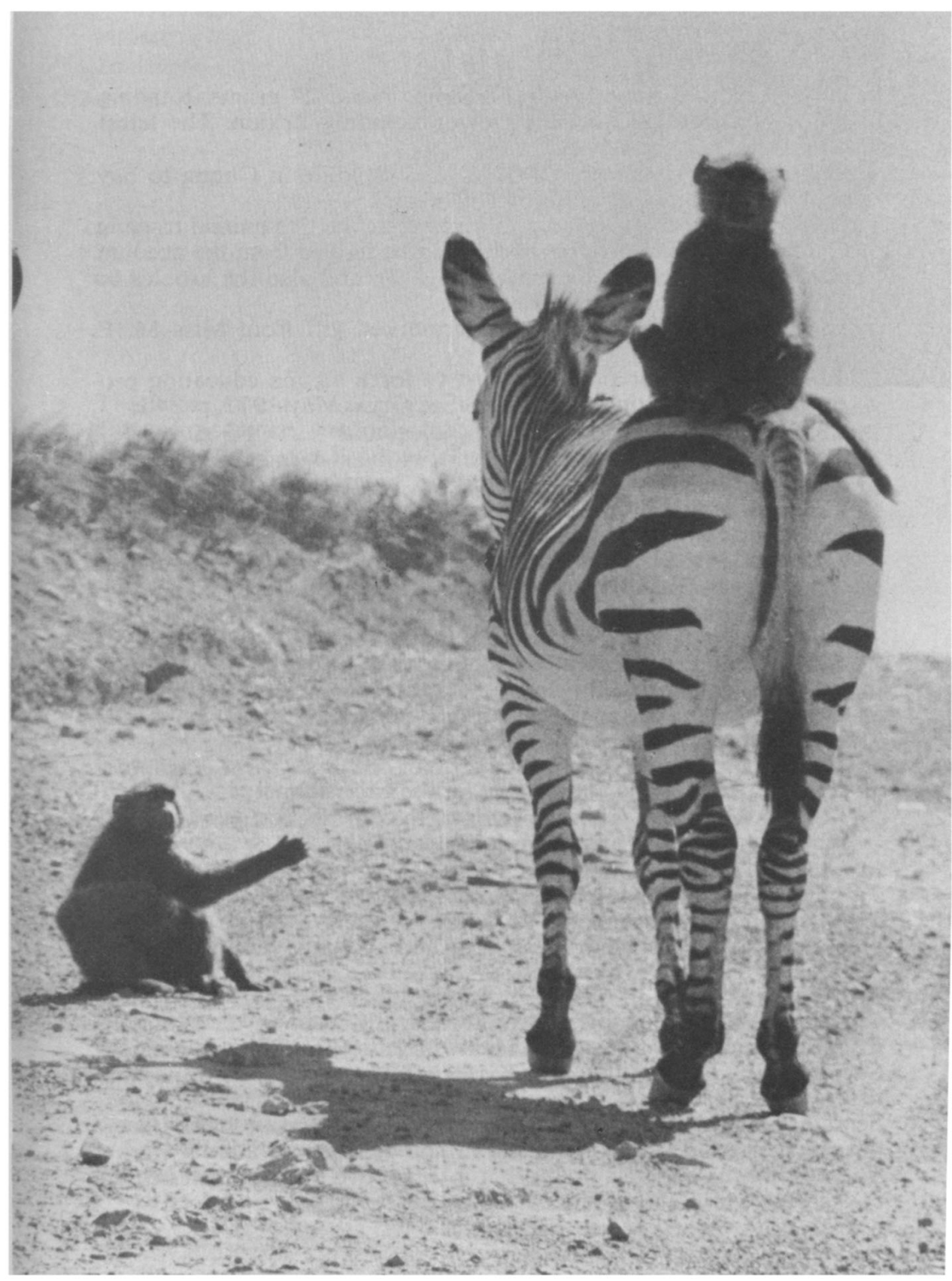

HITCH HIKING in the Cape Province, Hugh Cressy-Hall 